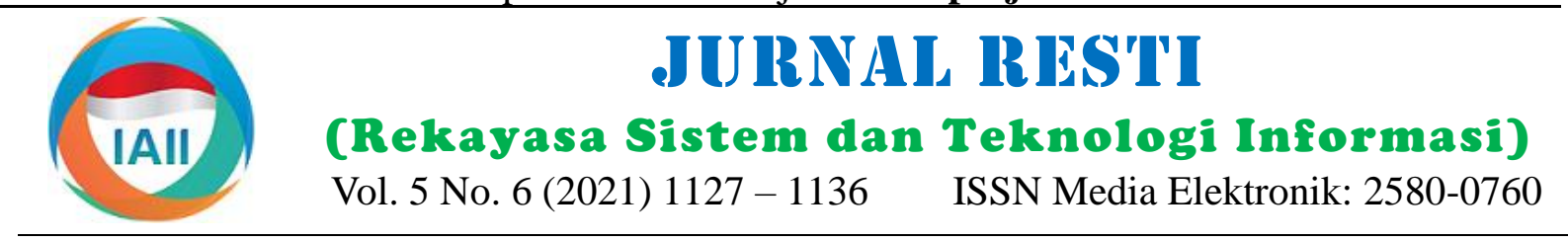

\title{
Analisis Hybrid Decision Support System dalam Penentuan Status Kelulusan Mahasiswa
}

\author{
Dodi Guswandi ${ }^{1}$, Musli Yanto ${ }^{2}$, M. Hafizh ${ }^{3}$, Liga Mayola ${ }^{4}$ \\ ${ }^{1,4}$ Sistem Informasi, Fakultas Ilmu Komputer, Universitas Putra Indonesia YPTK Padang \\ ${ }^{2,3}$ Teknik Informatika, Fakultas Ilmu Komputer, Universitas Putra Indonesia YPTK Padang \\ 19uswandidodi@upiyptk.ac.id, ${ }^{2}$ musli_yanto@ upiyptk.ac.id, ${ }^{3}$ muhammad_hafizh@upiyptk.ac.id, ${ }^{4}$ ligamayola@ upiyptk.ac.id
}

\begin{abstract}
Determination of graduation status is often faced by lecturers in every university. The facts show that many of the decisions still have a fairly high error rate in determining graduation status. This study aims to develop an analytical model in the process of determining student graduation using the Hybrid Decision Support System (DSS). The methods used in the analysis process are Analytical Hierarchy Process (AHP) and Technique for Others Preference by Similarity to Ideal Solution (TOPSIS). The performance of AHP can determine the value of the weight criteria and TOPSIS performs rankings to produce solutions in determining. The criteria indicators used to consist of Depth (C1), Material Breadth (C2), Answer Accuracy (C3), Fluency of Answers (C4), Scientific Attitude (C5), Logical Consistency of Content (C6), Authenticity (C7), Scientific Quality ( C8), Language (C9), and Writing (C10). The results of this study indicate that the Analytical Hierarchy Process (AHP) method provides a weighting value for each criterion with a fairly good accuracy rate of $85,86 \%$. These results conclude that each criterion has a consistent level of relationship in determining student graduation. Based on the output of the TOPSIS analysis, the results presented can determine the student's graduation status correctly and accurately.
\end{abstract}

Keywords: Comprehensive, Hybrid Decision Support System, Analytical Hierarchy Process (AHP), Technique for Others Preference by Similarity to Ideal Solution (TOPSIS).

\begin{abstract}
Abstrak
Penentuan status kelulusan sering dihadapi oleh para dosen di setiap perguruan tinggi. Fakta yang ada mengambarkan bahwa masih banyak diantara beberapa keputusan masih memiliki tingkat kesalahan yang cukup tinggi dalam menentukan status kelulusan. Penelitian ini bertujuan untuk mengembangkan model analisis dalam proses penentuan kelulusan mahasiswa pada ujian komprehensif menggunakan Hybrid Decision Support System (HDSS). Metode yang digunakan dalam proses analisis yakni penggabungan metode Analytical Hiererchy Process (AHP) dengan Technique for Others Preference by Similarity to Ideal Solution (TOPSIS). Kinerja metode AHP mampu menentukan nilai bobot kriteria dan TOPSIS melakukan perankingan untuk menghasilkan solusi dalam penentuan status kelulusan. Indikator kriteria yang digunakan terdiri dariKedalaman (C1), Keluasan Bahan (C2), Ketepatan Jawaban (C3), Kelancaran Jawaban (C4), Sikap Ilmiah (C5), Konsistensi Logis Isi (C6), Keaslian (C7), Mutu Ilmiah (C8), Bahasa (C9), dan Tata Tulis (C10). Hasil penelitian ini menunjukan bahwa kinerja HDSS signifikan memberikan proses analisis yang lebih baik dengan tingkat akurasi sebesar $85,86 \%$. Hasil ini tersaji dengan kinerja AHP dapat memberikan nilai pembobotan pada setiap kriteria yang nantinya diteruskan dengan metode TOPSIS dalam menentukan status kelulusan mahasiswa dengan melakukan perangkingan. Secara keseluruhan hasil ini menyimpulkan bahwa setiap kriteria memiliki tingkat hubungan konsistensi dalam penentuan kelulusan mahasiswa.
\end{abstract}

Kata kunci: Komprehensif, Hybrid Decision Support System, Analytical Hierarchy Process (AHP), Technique for Others Preference by Similarity to Ideal Solution (TOPSIS).

\section{Pendahuluan}

Status kelulusan merupakan salah satu permasalahan yang selalu dihadapi oleh perguruan tinggi yakni tidak tepatnya menentukan status kelusan mahasiswa[1]. Pada dasarnya kelulusan mahasiswa menjadi pengaruh besar terhadap penilaian sebuah perguruan tinggi[2]. Permasalahan yang terlihat bahwa masih banyak pada beberapa hasil kelulusan memiliki ketidakpastian sehingga memberikan dampak pada status kelulusan[3]. Sehingga dalam hal ini sangat dibutuhkan sebuah model

Diterima Redaksi: 29-10-2021 | Selesai Revisi: 22-12-2021 | Diterbitkan Online: 30-12-2021 
analisis yang digunakan sebagai alat dalam sebuah pengambilan keputusan[4].

Perkembangan sistem pengambilan keputusan pada era revolusi industri 4.0 sekarang ini berkembang cukup pesat[5]. Hal ini seiring dengan perkembangan teknologi dan konsep yang telah dihasilkan untuk mengatasi berbagai macam masalah[6]. Salah satu konsep yang berperan aktif dalam hal tersebut yakni Decision Support System (DSS). Konsep ini mampu menyajikan hasil keluaran yang dapat membantu dalam pengambilan keputusan[7]. Tidak hanya itu konsep DSS juga mampu menghasilkan sebuah pengetahuan baru yang tersembunyi dari sebuah data[8].

Pada dasarnya DSS merupakan sebuah teknik dalam bentuk himpunan/kumpulan berbasis model yang dapat secara interaktif dalam pengambilan keputusan[9]. DSS berfungsi untuk membantu pengambilan keputusan dalam mengatasi masalah terstruktur dan semi struktur agar lebih efektif dengan menggunakan model analitis dan data yang tersedia[10]. Keputusan yang diambil untuk menyelesaikan suatu masalah dilihat dari keterstrukturannya yang terdiri dari keputusan terstruktur (Structured Decision), keputusan semi terstruktur (Semi Structured Decision), dan keputusan tak terstruktur (Unstructured Decision)[11]. Sejauh ini konsep DSS telah berkembang pesat dalam menyelesaikan beberapa permasalahan[12]. Sehingga
dengan penerapan DSS mampu memberikan hasil yang cukup efektif pada sebuah masalah[13].

Penerapan DSS dalam permasalahan status kelulusan sudah dikembangkan sebelumnya. Hasil penelitian yang sudah ada menjelaskan bahwa DSS dapat memberikan rekomendasi kelulusan pada ujian komprehensif mahasiswa dengan hasil akurasi yang cukup baik dan dijadikan bahan pengambilan keputusan[14]. Pada permasalahan yang sama menjelaskan bahwa konsep DSS dalam Business Intelligence (BI) diaplikasikan untuk pengambilan keputusan status kelulusan[15]. Pemaparan lainnya juga menjelaskan bahwa penentuan kelulusan dapat diaplikasikan pada jaringan saraf untuk menghasilkan penilaian yang tepat pada status kelulusan sidang skripsi[16]. Berdasarkan uraian tersebut dapat dilihat bahwa permasalahan penentuan kelulusan menjadi perhatian khusus untuk memberikan solusi yang terbaik.

Penelitian membahas permasalahan dalam penentuan status kelulusan mahasiswa dengan mengembangkan konsep DSS dalam bentuk Hybrid Decision Support System (HDSS). Konsep ini mengadopsi metode Analytical Hiererchy Process (AHP), dan Technique for mahasiswa.

Others Preference by Similarity to Ideal Solution (TOPSIS). Kinerja metode tersebut dapat menyajikan hasil dalam bentuk rekomendasi pengambilan keputusan[17]. Kombinasi AHP dan TOPSIS dikembangkan dengan tujuan untuk memberikan hasil yang optimal[18]. Kinerja AHP memberikan keluaran dengan pembobotan yang terbaik[19]. Dalam penjelasan lainnya metode AHP memberikan gambaran awal dalam pembobotan guna menyajikan rekomendasi cukup baik dalam pengambilan keputusan[20].

Dalam pengembangannya metode AHP dapat dikombinasikan dengan tujuan meminimalkan kesalahan proses pembobotan berdasarkan kriteria[21]. Pembobotan yang didapat akan dimaksimalkan metode TOPSIS untuk melakukan perhitungan guna mendapatkan perangkingan berdasarkan keluaran[22]. Metode TOPSIS memberikan hasil keluaran dengan bentuk jarak solusi ideal dari kriteria[23]. Jarak yang dihasilkan akan dianalisis dalam gambaran hasil perangkingan untuk dijadikan solusi dalam penyelesaian sebuah masalah[23]. Dengan penjelasan tersebut, metode AHP dan Topsis dapat memaksimalkan proses analisis guna memberikan hasil solusi yang lebih baik[24].

Penerapan metode AHP dan TOPSIS mampu menggambarkan perangkingan dengan menggunakan Multi-Criteria Decision-Making (MCDM)[25]. Dalam hasil penelitian sebelumnya memaparkan bahwa metode AHP dan TOPSIS telah memberikan hasil yang tepat dalam penentuan karyawan terbaik[26]. Pendekatan AHP dan TOPSIS juga mampu memberikan gambaranhasil keluaran yang cukup baik dengan menetapkan bobot dan kriteria dalam setiap proses analisis yang dilakukan[27]. Dalam hal lainnya menjelaskan bahwa konsep HDSS menyajikan hasil keluaran yang signifikan[28],[29].

Berdasarkan literatur penelitian sebelumnya konsep HDSS dapat digunakan dalam penentuan kelulusan mahasiswa. Penelitian ini akan mengembangkan model penentuan dengan menerapkan metode AHP dan Topsis untuk memberikan keluaran yang dapat dijadikan rujukan dalam pengambilan keputusan. Kombinasi metode tersebut mampu menyempurnakan model sebelumnya dengan hasil akurasi ketepatan yang cukup penentuan kelulusan mahasiswa memberikan memudahkan dosen penguji pada ujian komprehensif.

Secara keseluruhan penelitian ini menyajikan keterbaharuan proses analisis yang terstruktur untuk menghasilkan keluaran yang tepat dan akurat. Sajian keterbaharuan tersebut mampu menyelesaikan masalah dalam penentuan status kelulusan mahasiswa dengan memberikan perangkingan pada setiap keputusan yang dihasilkan. hasil perangkingan akan menjadi tolak ukur dalam pengambilan keputusan status kelulusan

\section{Metodologi Penelitian}

Penelitian ini mengadopsi pendekatan dengan model kualitatif dengan menyajikan perhitungan matematis dalam penyelesaian sebuah masalah[30]. Pendekatan baik. Dengan ini secara umum penelitian dalam proses 
kualitatif telah banyak digunakan pada proses analisis nilai $\mathrm{CR} \leq 0,1$ maka hasilnya konsisten dimana nilai dengan mengkaji ketepatan hasil perhitungan bobotnya dapat digunakan untuk langkah selanjutnya berdasarkan konsep yang digunakan[31]. Paremeter yaitu analisis data dengan metode TOPSIS. Pada analisis pendekatan yang digunakan didasari pada konsep serta metode TOPSIS, nilai bobot yang sudah konsisten dari metode yang mengadopsi perhitungan secara matematis metode AHP akan dikalkulasikan dalam menentukan dalam melakukan analisis. Konsep HDSS dengan matriks keputusan ternomalisasi terbobot pada langkah melibatkan metode AHP dan Topsis dapat dimodelkan ke 3, dan selanjutnya nilai hasil keputusan disajikan talam tahapan analisis yang dilakukan. Adapun tahapan dalam bentuk perankingan. Adapun variable indikator penelitian tersebut terdapat pada Gambar 1 .

yang digunakan dapat dilihat pada Tabel 1.

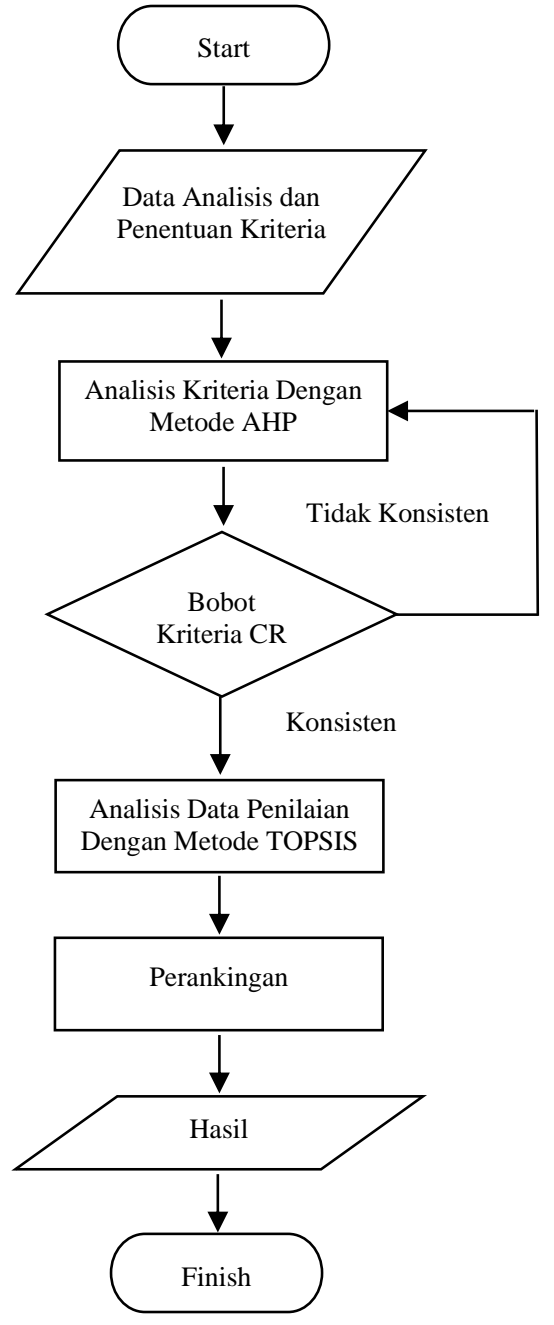

Gambar 1. Kerangka Kerja Penelitian

Gambar 1 menjelaskan tahapan penelitian yang dimulai dari proses analisa data, pembentukan kriteria, analisis dengan metode AHP, analisis dengan metode TOPSIS untuk mendapatkan hasil keputusan berupa perankingan. Pada proses analisis AHP hasil yang diharapkan mampu memberikan nilai bobot yang konsisten, nilai konsistensi yang disebut dengan nilai rasio consistency $(\mathrm{CR})$ yaitu $\leq 0,1$ yang merupakan nilai ambang batas (threshold) yang sudah ditetapkan oleh penemu metode ini[32]. Jika hasil nilai $\mathrm{CR}>0,1$ maka nilai kriteria perbandingan berpasangan yang sudah diuji hasilnya tidak konsisten dan diulang kembali pemilihan nilai perbandingan berpasangan pada langkah ke 3 . Jika

\begin{tabular}{ccl}
\multicolumn{3}{c}{ Tabel 1 Kriteria Ujian Komprehensif } \\
\hline No & Kode & \multicolumn{1}{c}{ Kriteria } \\
\hline 1 & C1 & Kedalaman \\
2 & C2 & Keluasan Bahan \\
3 & C3 & Ketepatan Jawaban \\
4 & C4 & Kelancaran Jawaban \\
5 & C5 & Sikap Ilmiah \\
6 & C6 & Konsistensi Logis Isi \\
7 & C7 & Keaslian \\
8 & C8 & Mutu Ilmiah \\
9 & C9 & Bahasa \\
10 & C10 & Tata Tulis \\
\hline
\end{tabular}

Tabel 1 Menjelaskan bahwa kriteria yang digunakan dalam penilaian diinisialisasi dengan kode $\mathrm{C} 1, \mathrm{C} 2, \mathrm{C} 3$, C4, C5, C6, C7, C8, C9, dan C10. Adapun gambaran metode AHP dapat lihat berdasakan Langkah-langkah berikut[33],[34]:

1. Mendefinisikan masalah, menentukan tujuan, kriteria, sub kriteria dan alternatif solusi.

2. Membuat struktur hirarki dari atas ke bawah yaitu tujuan, kriteria, sub kriteria dan alternatif solusi.

3. Membuat matriks perbandingan berpasangan (pairwise comparison) kriteria. Perbadingan dilakukan berdasarkan "judgment" dari pengambil keputusan dengan menilai tingkat kepentingan suatu elemen dibandingkan elemen lainnya.

4. Nilai kriteria perbandingan berdasarkan pada Tabel 2.

Tabel 2 Nilai Skala Penilaian Perbandingan Berpasangan

\begin{tabular}{|c|c|c|}
\hline Intensitas & Keterangan & Penjelasan \\
\hline 1 & $\begin{array}{l}\text { Kedua elemen } \\
\text { sama pentingnya }\end{array}$ & $\begin{array}{l}\text { Dua elemen mempunyai } \\
\text { pengaruh yang sama besar } \\
\text { terhadap tujuan. }\end{array}$ \\
\hline 3 & $\begin{array}{lr}\text { Elemen yang satu } \\
\text { sedikit lebih } \\
\text { penting dari pada } \\
\text { elemen } \quad \text { yang }\end{array}$ & $\begin{array}{l}\text { Pengalaman dan penilaian } \\
\text { sedikit menyokong satu elemen } \\
\text { dibandingkan elemen lainnya. }\end{array}$ \\
\hline 5 & $\begin{array}{l}\text { Elemen yang satu } \\
\text { lebih penting dari } \\
\text { elemen lainnya. }\end{array}$ & $\begin{array}{l}\text { Pengalaman dan penilaian sangat } \\
\text { kuat menyokong satu elemen } \\
\text { dibandingkan elemen yang } \\
\text { lainnya. }\end{array}$ \\
\hline 7 & $\begin{array}{l}\text { Satu elemen jelas } \\
\text { lebih mutlak } \\
\text { penting dari pada } \\
\text { elemen lainnya. }\end{array}$ & $\begin{array}{l}\text { Satu elemen yang kuat disokong } \\
\text { dan dominan terlihat dalam } \\
\text { praktek. }\end{array}$ \\
\hline 9 & $\begin{array}{ll}\text { Satu } & \text { elemen } \\
\text { mutlak } & \text { penting } \\
\text { dari pada } & \text { elemen } \\
\text { lainnya. } & \end{array}$ & $\begin{array}{lrr}\text { Bukti yang mendukung } & \text { elemen } \\
\text { yang satu terhadap } & \text { elemen } \\
\text { lainnya } & \text { memiliki } & \text { tingkat } \\
\text { penegasan } & \text { tertinggi } & \text { yang }\end{array}$ \\
\hline
\end{tabular}




$\begin{array}{cll}2,4,6, & \begin{array}{l}\text { Nilai-nilai antara Nilai ini diberikan bila ada dua } \\ 8\end{array} & \begin{array}{l}\text { dua nilai } \\ \text { pertimbangan }\end{array} \\ & \text { yang berdekatan }\end{array}$

5. Menghitungan matriks bobot nilai antar kriteria dan prioritas.

6. Menghitung matrik penjumlahan setiap baris atau Menghitung vektor eigen dari setiap matriks perbandingan berpasangan.

7. Menghitung nilai rasio konsistensi kriteria. Jika nilai rasio consistency $(\mathrm{CR}) \leq 0,1$ maka penilaian yang dilakukan adalah konsisten, dengan menggunakan Persamaan 1\&2 [35]:

$$
\begin{aligned}
& C I=\frac{(\lambda \max -n)}{(n-1)} \\
& C R=\frac{C I}{I R}
\end{aligned}
$$

Menentukan nilai indek random (IR) dapat dilihat pada Tabel 3[36].

Tabel 3. Nilai Indeks Random

\begin{tabular}{cccccc}
\hline Ordo Matrik & RI & Ordo Matrik & RI & Ordo Matrik & RI \\
\hline 1 & 0 & 6 & 1,24 & 11 & 1,51 \\
2 & 0 & 7 & 1,32 & 12 & 1,48 \\
3 & 0,58 & 8 & 1,41 & 13 & 1,56 \\
4 & 0,9 & 9 & 1,45 & 14 & 1,57 \\
5 & 1,12 & 10 & 1,49 & 15 & 1,59 \\
\hline
\end{tabular}

Tabel 3 dapat dilihat bahwa nilai indeks random yang digunakan dalam perhitungan metode AHP terdiri dari Ordo Matriks dan Nilai Indeks Random. Tahapan selanjutnya adalah melakukan perhitungan dengan menggunakan metode Topsis. Adapun Langkah-langkah yang akan dilakukan dapat dilihat sebagai berikut[37]:

1. TOPSIS dimulai dengan membangun sebuah matriks keputusan. Matriks keputusan X mengacu terhadap $m$ alternatif yang akan dievaluasi berdasarkan $n$ kriteria. Matriks keputusan X dapat dilihat pada Persamaan.3.

$$
X=\stackrel{a_{1}}{\vdots} a_{m}\left[\begin{array}{ccc}
x_{11} & \cdots & x_{1 n} \\
\vdots & \ddots & \vdots \\
x_{m 1} & \cdots & x_{m n}
\end{array}\right]
$$
Persamaan. 3 menjelaskan bahwa ai $(\mathrm{i}=1,2,3, \ldots, \mathrm{m})$
adalah alternatif-alternatif yang mungkin, $x j(\mathrm{j}=1,2,3$, ..., n) adalah atribut dimana performansi alternatif diukur, $x i j$ adalah performansi alternatif ai dengan acuan atribute $x j$.

2. Membuat matriks bobot keputusan yang ternormalisasi. TOPSIS membutuhkan rating kinerja setiap alternatif Ai pada setiap bobot rij yang ternormalisasi seperti pada Persamaan.4.

$r i j=\frac{X_{i j}}{\sum_{i}^{m} X_{i j}{ }^{2}}$ dengan $\mathrm{i}=1,2,3, \ldots, \mathrm{m} ;$ dan $\mathrm{j}=1,2,3, \ldots, \mathrm{n} ;$ dimana $r i j$ adalah elemen dari matriks keputusan yang ternormalisasi R. $x i j$ adalah elemen matriks dari keputusan X.

3. Membuat matriks keputusan yang ternormalisasi terbobot.

Dengan bobot $w i=w 1, w 2, w 3, \ldots, w n$ dimana $w j$ adalah bobot dari kriteria ke-j dan $n j=1 w j=1$ maka normalisasi bobot matriks V seperti pada Persamaan.5.

$$
v i j=w j \cdot r i j
$$

dengan $i=1,2,3, \ldots, m ;$ dan $j=1,2,3, \ldots, n$; dimana $v i j$ adalah elemen dari matriks keputusan yang ternormalisasi terbobot $\mathrm{V}$.

$w i j$ adalah bobot dari kriteria ke-j. rij adalah elemen dari matriks keputusan yang ternormalisasi R.

4. Menentukan matriks solusi ideal positif dan solusi ideal negatif.

Solusi ideal positif dinotasikan $A+$, sedangkan solusi ideal negatif dinotasikan $A^{-}$. Berikut ini adalah Persamaan $6 \& 7$ dari $A+$ dan $A-$ :

$A^{+}=\left(y_{1}^{+}, y_{2}^{+}, \ldots . y_{n}^{+}\right)(6)$

$A^{-}=\left(y_{1}^{-}, y_{2}^{-}, \ldots . y_{n}^{-}\right)(7)$

\section{Menghitung Separasi}

$S+$ adalah jarak alternatif dari solusi ideal positif didefenisikan pada Persamaan.8.

$\mathrm{S}_{i}^{+}=\sqrt{\sum_{j=1}^{n}\left(v_{i j}-v_{j}^{+}\right)^{2}}(8)$

$S$ - adalah jarak alternatif dari solusi ideal negatif didefenisikan pada Persamaan.9.

$\mathrm{S}_{i}^{-}=\sqrt{\sum_{j=1}^{n}\left(v_{i j}-v_{j}^{-}\right)^{2}}(9)$

Dimana:

$\mathrm{S}_{i}^{+}$adalah jarak alternatif ke-I dari solusi ideal positif,

$\mathrm{S}_{i}^{-}$adalah jarak alternatif ke-I dari solusi ideal negatif,

$v_{i j}$ adalah elemen dari matriks keputusan yang ternormaslisasi terbobot $\mathrm{V}$,

$v_{j}^{+}$adalah elemen matriks solusi ideal positif,

$v_{j}^{-}$adalah elemen matriks solusi ideal negatif.

6. Menghitung kedekatan relatif terhadap solusi ideal positif $\left(c_{i}^{+}\right)$pada persamaan 10 dibawah ini:

$$
c_{i}^{+}=\frac{s_{i}^{-}}{\left(s_{i}^{-}+s_{i}^{+}\right)}(10)
$$

7. Meranking Alternatif dengan melakukan pengurutan $\mathrm{C}+$ terbesar ke nilai terkecil. Alternatif dengan nilai $\mathrm{C}+$ terbesar merupakan solusi yang terbaik.

\section{Hasil dan Pembahasan}

DOI: https://doi.org/10.29207/resti.v5i6.3587

Lisensi: Creative Commons Attribution 4.0 International (CC BY 4.0) 


\subsection{Analisis metode Hybrid DSS}

Dalam menyelesaikan masalah ini pembahasan dimulai dari pembetukan struktur hirarki metode AHP yang dimulai dari atas kebawah. Struktur ini bertujuan untuk menemukan alternatif solusi berdasarkan indicator kriteria yang terdapat pada Tabe.1. Adapun bentuk gambaran dari struktur hirarki metode AHP dapat dilihat pada Gambar 2.

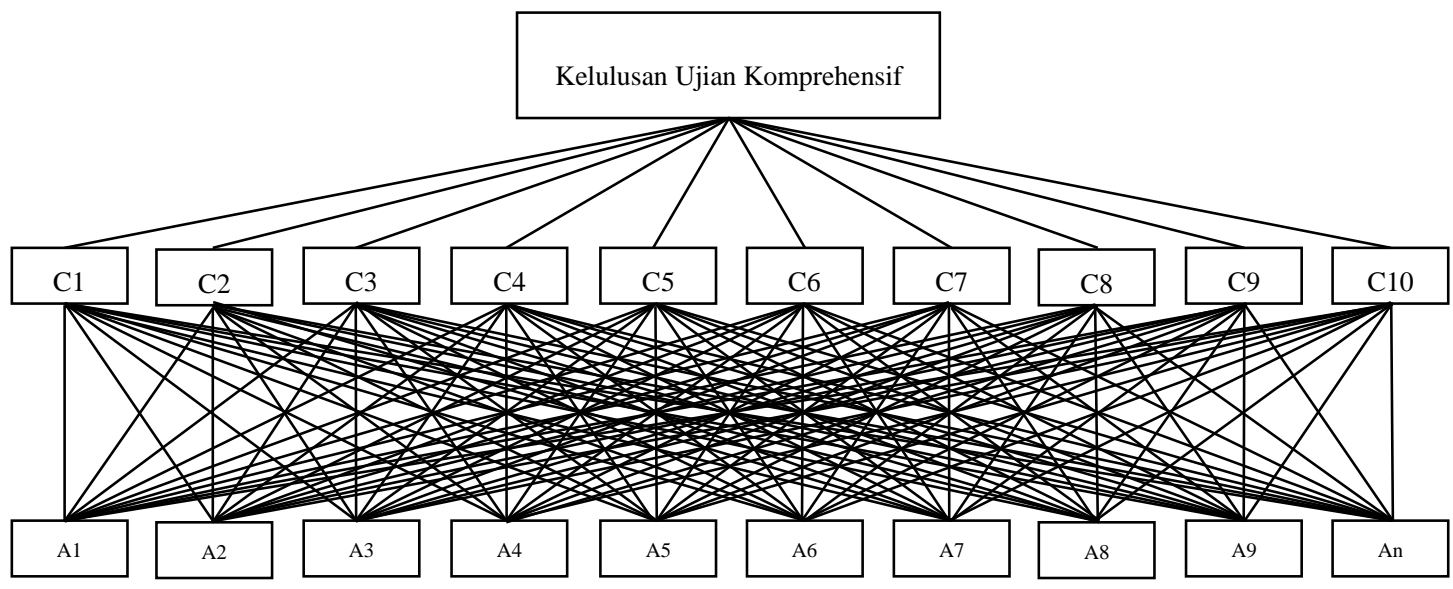

Gambar 2. Struktur Hirarki AHP

Gambar 2 menjelaskan bahwa struktur hirarki menggambarkan proses pengolahan data dengan metode AHP dengan melihat relasi antara masalah kriteria dan alternatif. Masalah yang akan diatasi adalah menentukan kelulusan dengan 10 kriteria yang terdapat pada Tabel 1. Untuk alternatif di inisialkan dengan A1, A2, A3, A4, A5, A6, A7, A8, A9, An. Setelah struktur hirarki terbentuk maka proses dilanjutkan untuk membuat matriks perbandingan berpasangan (Pairwise Comparison) kriteria. Adapun matrik berpasangan yang terbentuk dapat dilihat pada Tabel 4.

Tabel 4. Perbandingan Berpasangan

\begin{tabular}{ccccccccccc}
\hline Kriteria & C1 & C2 & C3 & C4 & C5 & C6 & C7 & C8 & C9 & C10 \\
\hline C1 & 1 & 2 & 3 & 3 & 4 & 5 & 5 & 7 & 7 & 8 \\
C2 & 0,5 & 1 & 2 & 3 & 5 & 5 & 6 & 6 & 7 & 7 \\
C3 & 0,33 & 0,5 & 1 & 2 & 3 & 4 & 5 & 5 & 7 & 8 \\
C4 & 0,33 & 0,33 & 0,5 & 1 & 3 & 3 & 4 & 5 & 7 & 8 \\
C5 & 0,25 & 0,2 & 0,33 & 0,33 & 1 & 2 & 3 & 3 & 5 & 7 \\
C6 & 0,2 & 0,2 & 0,25 & 0,33 & 0,5 & 1 & 2 & 3 & 5 & 7 \\
C7 & 0,2 & 0,17 & 0,2 & 0,25 & 0,33 & 0,5 & 1 & 3 & 4 & 7 \\
C8 & 0,14 & 0,17 & 0,2 & 0,2 & 0,33 & 0,33 & 0,33 & 1 & 3 & 5 \\
C9 & 0,14 & 0,14 & 0,14 & 0,14 & 0,2 & 0,25 & 0,25 & 0,33 & 1 & 3 \\
C10 & 0,13 & 0,14 & 0,13 & 0,13 & 0,14 & 0,14 & 0,14 & 0,2 & 0,33 & 1 \\
JML & $\mathbf{3 , 2 2}$ & $\mathbf{4 , 8 5}$ & $\mathbf{7 , 7 5}$ & $\mathbf{1 0 , 3 8}$ & $\mathbf{1 7 , 5}$ & $\mathbf{2 1 , 2 2}$ & $\mathbf{2 6 , 7 2}$ & $\mathbf{3 3 , 5 3}$ & $\mathbf{4 6 , 3 3}$ & $\mathbf{6 1}$ \\
\hline
\end{tabular}

Matriks perbandingan berpasangan merupakan nilai dari skala perbandingan berpasangan yang terdapat pada Tabel 1 dimana masing-masing kriteria akan dibandingkan secara berpasangan berdasarkan tingkat kepentingannya. Setelah matrik pesangan dihasilkan maka proses dilanjutkan Kembali untuk menentukan nilai bobot antar kriteria dan prioritas. Adapun hasil bobot antar kriteria dapat disajikan pada Tabel 5.

Tabel 5. Nilai Bobot Antar Kriteria Dan Prioritas

\begin{tabular}{ccccccccccccc}
\hline K & C1 & C2 & C3 & C4 & C5 & C6 & C7 & C8 & C9 & C10 & JML & P \\
\hline C1 & 0,311 & 0,412 & 0,387 & 0,289 & 0,229 & 0,236 & 0,187 & 0,209 & 0,151 & 0,131 & 2,541 & 0,254 \\
C2 & 0,155 & 0,206 & 0,258 & 0,289 & 0,286 & 0,236 & 0,225 & 0,179 & 0,151 & 0,115 & 2,099 & 0,210 \\
C3 & 0,102 & 0,103 & 0,129 & 0,193 & 0,171 & 0,189 & 0,187 & 0,149 & 0,151 & 0,131 & 1,506 & 0,151 \\
C4 & 0,102 & 0,068 & 0,065 & 0,096 & 0,171 & 0,141 & 0,150 & 0,149 & 0,151 & 0,131 & 1,225 & 0,123 \\
C5 & 0.078 & 0,041 & 0,043 & 0,032 & 0,057 & 0,094 & 0,112 & 0,089 & 0,108 & 0,115 & 0,769 & 0,077
\end{tabular}

$\begin{array}{lllllllllllll}\text { C6 } & 0,062 & 0,041 & 0,032 & 0,032 & 0,029 & 0,047 & 0,075 & 0,089 & 0,108 & 0,115 & 0,630 & 0,063\end{array}$ $\begin{array}{lllllllllllll}\text { C7 } & 0,062 & 0,035 & 0,026 & 0,024 & 0,019 & 0,024 & 0,037 & 0,089 & 0,086 & 0.115 & 0,517 & 0,052\end{array}$ $\begin{array}{lllllllllllll}\text { C8 } & 0,043 & 0,035 & 0,026 & 0,019 & 0,019 & 0,016 & 0,012 & 0,030 & 0,065 & 0,082 & 0,347 & 0,035\end{array}$

Tabel 5 merupakan tahapan dalam penentuan nilai prioritas bobot setiap kriteria, total semua nilai bobot adalah 1 atau 100. Setelah nilai bobot antar kriteria didapat maka proses masih dilanjutkan untuk menghitung nilai vektor eigen dari setiap nilai kriteria perbandingan berpasangan. Adapun hasil tersebut dapat dilihat pada Tabel 6

Tabel 6. Nilai Vektor Eigen

\begin{tabular}{cccccccccccc}
\hline K & C1 & C2 & C3 & C4 & C5 & C6 & C7 & C8 & C9 & C10 & JML \\
\hline C1 & 0,254 & 0,420 & 0,452 & 0,368 & 0,308 & 0,315 & 0,259 & 0,243 & 0,152 & 0,118 & 2,888 \\
C2 & 0,127 & 0,210 & 0,301 & 0,368 & 0,385 & 0,315 & 0,310 & 0,208 & 0,152 & 0,103 & 2,479 \\
C3 & 0,084 & 0,105 & 0,151 & 0,245 & 0,231 & 0,252 & 0,259 & 0,173 & 0,152 & 0,118 & 1,770 \\
C4 & 0,084 & 0,069 & 0,075 & 0,123 & 0,231 & 0,189 & 0,207 & 0,173 & 0,152 & 0,118 & 1,421 \\
C5 & 0,064 & 0,042 & 0,050 & 0,040 & 0,077 & 0,126 & 0,155 & 0,104 & 0,109 & 0,103 & 0,870 \\
C6 & 0,051 & 0,042 & 0,038 & 0,040 & 0,038 & 0,063 & 0,103 & 0,104 & 0,109 & 0,103 & 0,692 \\
C7 & 0,051 & 0,036 & 0,030 & 0,031 & 0,025 & 0,032 & 0,052 & 0,104 & 0,087 & 0,103 & 0,550 \\
C8 & 0,036 & 0,036 & 0,030 & 0,025 & 0,025 & 0,021 & 0,017 & 0,035 & 0,065 & 0,074 & 0,363 \\
C9 & 0,036 & 0,029 & 0,021 & 0,017 & 0,015 & 0,016 & 0,013 & 0,011 & 0,022 & 0,044 & 0,225 \\
C10 & 0,033 & 0,029 & 0,020 & 0,016 & 0,011 & 0,009 & 0,007 & 0,007 & 0,07 & 0,015 & 0,154 \\
\hline
\end{tabular}

Untuk mendapatkan nilai vector eigen berdasarkan proses perkalian antara nilai prioritas dan nilai matriks perbandingan berpasangan. Setelah matriks vector eigen didapatkan maka proses perhitungan rasio dapat dilihat pada Tabel 7.

Tabel 7. Nilai Jumlah

\begin{tabular}{ccc}
\hline Jumlah & Prioritas & Hasil \\
\hline 2,888 & 0,254 & 11,370 \\
2,479 & 0,210 & 11,805 \\
1,770 & 0,151 & 11,722 \\
1,421 & 0,123 & 11,553 \\
0,870 & 0,077 & 11,299 \\
0,692 & 0,063 & 10,984 \\
0,550 & 0,052 & 10,577 \\
0,363 & 0,035 & 10,371 \\
0,225 & 0,022 & 10,227
\end{tabular}

DOI: https://doi.org/10.29207/resti.v5i6.3587

Lisensi: Creative Commons Attribution 4.0 International (CC BY 4.0) 


\begin{tabular}{rr}
0,154 & 0,015 \\
& 10,267 \\
& 110,175 \\
\hline
\end{tabular}

Kolom jumlah dan kolom prioritas pada Tabel 7 diatas berasal dari langkah sebelumnya, pada langkah ini digunakan untuk mendapatkan nilai jumlah keseluruhan digunakan untuk langkah selanjutnya dibawah ini.

$\lambda \max =\frac{110,175}{10}=11,017$

$C I=\frac{(\lambda \max -n)}{(n-1)}=\frac{(11,017-10)}{(10-1)}=\frac{1,017}{9}=0,113$

$C R=\frac{0,113}{1,49}=0,076$

Oleh karena nilai $\mathrm{CR} \leq 0.1$, maka nilai perbandingan kriteria berpasangan adalah konsisten dan dapat dilanjutkan kelangkah selanjutnya.

\subsection{Proses Perhitungan Metode TOPSIS}

Langkah 1: TOPSIS dimulai dengan membangun sebuah matriks keputusan. Matriks keputusan $\mathrm{X}$ mengacu terhadap $\mathrm{m}$ alternatif yang akan dievaluasi berdasarkan n kriteria. Matriks keputusan X dapat dilihat pada Tabel 8.

Tabel 8. Nilai Bobot Antar Kriteria Dan Prioritas

\begin{tabular}{ccccccccccc}
\hline \multirow{2}{*}{ Alternatif } & \multicolumn{10}{c}{ Kriteria } \\
\cline { 2 - 10 } & C1 & C2 & C3 & C4 & C5 & C6 & C7 & C8 & C9 & C10 \\
\hline A1 & 70 & 70 & 75 & 65 & 80 & 70 & 70 & 65 & 65 & 65 \\
A2 & 75 & 75 & 75 & 70 & 75 & 65 & 70 & 65 & 70 & 70 \\
A3 & 60 & 65 & 60 & 70 & 65 & 65 & 65 & 60 & 65 & 65 \\
A4 & 80 & 85 & 80 & 70 & 75 & 80 & 75 & 65 & 65 & 65 \\
A5 & 65 & 70 & 70 & 75 & 80 & 70 & 75 & 70 & 70 & 70 \\
A6 & 50 & 55 & 60 & 65 & 65 & 65 & 65 & 60 & 50 & 60 \\
A7 & 75 & 75 & 70 & 80 & 85 & 75 & 70 & 65 & 65 & 65 \\
A8 & 80 & 80 & 80 & 70 & 70 & 70 & 75 & 70 & 70 & 75 \\
A9 & 60 & 65 & 60 & 60 & 65 & 60 & 60 & 65 & 60 & 60 \\
A10 & 65 & 65 & 70 & 70 & 65 & 70 & 65 & 60 & 65 & 60 \\
\hline
\end{tabular}

Tabel ini menampilkan hasil penilaian dosen penguji terhadap mahasiswa telah mengikuti ujian komprehensif.

Langkah 2: Membuat matriks keputusan ternormalisasi Hasil yang disajikan pada Tabel 9 menggambarkan dari setiap ketegori yang dilambangkan dengan X(i) hasul nilai jarak solusi ideal positif dan negatif. Setelah dimana $\mathrm{i}=1,2$, 3, dan 4. Adapun rumus normalisasi hasil tersebut didapat maka tahapan dilanjutkan untuk matriks adalah sebagai berikut:

$$
\begin{aligned}
r i j & =\frac{x i j}{\sqrt{\sum_{i=1}^{m} x^{2} i j}} \\
R 11 & =\frac{70}{\sqrt{70^{2}+75^{2}+60^{2}+80^{2}+65^{2}+50^{2}+75^{2}+80^{2}+60^{2}+65^{2}}} \\
& =\frac{70}{\sqrt{47100}}=\frac{70}{217,0253}=0,323 \cdot \\
R & =\left[\begin{array}{lllllllllll}
0,323 & 0,312 & 0,337 & 0,295 & 0,347 & 0,320 & 0,320 & 0,318 & 0,317 & 0,313 \\
0,346 & 0,334 & 0,337 & 0,318 & 0,326 & 0,297 & 0,320 & 0,318 & 0,342 & 0,337 \\
0,276 & 0,290 & 0,270 & 0,318 & 0,282 & 0,297 & 0,297 & 0,294 & 0,317 & 0,313 \\
0,369 & 0,379 & 0,359 & 0,318 & 0,326 & 0,366 & 0,343 & 0,318 & 0,317 & 0,313 \\
0,300 & 0,312 & 0,314 & 0,340 & 0,347 & 0,320 & 0,343 & 0,343 & 0,342 & 0,337 \\
0,230 & 0,245 & 0,270 & 0,295 & 0,282 & 0,297 & 0,297 & 0,294 & 0,244 & 0,289 \\
0,346 & 0,334 & 0,314 & 0,363 & 0,369 & 0,343 & 0,320 & 0,318 & 0,317 & 0,313 \\
0,369 & 0,356 & 0,359 & 0,318 & 0,304 & 0,320 & 0,343 & 0,343 & 0,342 & 0,361 \\
0,276 & 0,290 & 0,270 & 0,272 & 0,282 & 0,274 & 0,274 & 0,318 & 0,293 & 0,289 \\
0,300 & 0,290 & 0,314 & 0,318 & 0,282 & 0,320 & 0,297 & 0,294 & 0,317 & 0,289
\end{array}\right]
\end{aligned}
$$
menghitung kedekatan relative dari setiap alternatif terhadap solusi ideal positif $\left(c_{i}^{+}\right)$. Hasil tersebut dapat dilihat pada Tabel 10 .

\begin{tabular}{cccc} 
Tabel 10 Hasil Kedekatan Relatif dai Alternatif Solu \\
\hline $\mathrm{I}$ & $\mathrm{S}^{+}$ & $\mathrm{S}^{-}$ & $C^{+}$ \\
\hline 1 & 0,020726 & 0,029979 & 0,591234 \\
2 & 0,014019 & 0,036956 & 0,724983 \\
3 & 0,034439 & 0,016183 & 0,319681 \\
4 & 0,006623 & 0,047921 & 0,878578 \\
5 & 0,023878 & 0,02599 & 0,52117 \\
6 & 0,048503 & 0,003357 & 0,064735 \\
7 & 0,013147 & 0,03807 & 0,743314 \\
8 & 0,009298 & 0,04503 & 0,828854 \\
9 & 0,03606 & 0,015047 & 0,294419 \\
10 & 0,028259 & 0,022027 & 0,43804 \\
\hline
\end{tabular}

DOI: https://doi.org/10.29207/resti.v5i6.3587

Lisensi: Creative Commons Attribution 4.0 International (CC BY 4.0) 
Tabel 10 menyajikan hasil kedekatan relative dari setiap alternatif. Tahap akhir proses ini melakukan proses perangkingan alternatif. Adapun hasil tersebut dapat dilihat pada Tabel 11 .

Tabel 11 Hasil Perangkingan Alternatif

\begin{tabular}{cccccc}
\hline No & Alternatif & $C^{+}$ & NA & NH & Ket \\
\hline 1 & A4 & 0,878578 & 87,8578 & A & Lulus \\
2 & A8 & 0,828854 & 82,8854 & A & Lulus \\
3 & A7 & 0,743314 & 74,3314 & B & Lulus \\
4 & A2 & 0,724983 & 72,4983 & B & Lulus \\
5 & A1 & 0,591243 & 59,1243 & C & Tidak \\
6 & A5 & 0,52117 & 52,117 & D & Tidak \\
7 & A10 & 0,43804 & 43,804 & D & Tidak \\
8 & A3 & 0,319681 & 31,9681 & E & Tidak \\
9 & A9 & 0,294419 & 29,4419 & E & Tidak \\
10 & A6 & 0,064735 & 6,4735 & E & Tidak \\
\hline
\end{tabular}

Tabel 11 merupakan hasil perangkingan menggunakan metode hybrid SPK. Dari hasil tersebut dapat dilihat bahwa terdapat 2 keputusan yaitu mahasiswa yang lulus dan tidak lulus dalam ujian kompre, dan nilai mahasiswa yang terbaik sampai yang terendah dapat diurutkan seperti pada tabel diatas. Dengan hasil ini secara awal dapat disimpulkan bahwa HDSS yang tergabung diantaranya metode AHP dan TOPSIS mampu menyajikan hasil keluaran yang optimal[38],[39]. Setelah hasil analisis status kelulusan didapat, maka proses masih berlanjut untuk mengukur kinerja dari proses analisis HDSS. Proses pengukuran menggunakan rumus uji validitas eksternal berdasarkan alternatif solusi dengan nilai jarak yang dihasilkan. adapun proses tersebut dapat disajikan pada perhitungan dengan menggunakan Persamaan.11[40].

$$
\operatorname{rxy}=\frac{\Sigma x y}{\sqrt{(\Sigma \mathrm{x} 2)(\mathrm{y} 2)}}(11)
$$

$$
\begin{aligned}
& =\frac{3,042413}{3,543143592} \times 100 \\
& =85,86 \%
\end{aligned}
$$

Berdasarkan pengukuran validitas menggunakan persamaan.11, keluaran proses analisis penentuan status kelulusan mahasiswa memberikan persentasehasil sebesar 85,86\%. Hasil ini menggambarkan bahwa konsep HDSS memberikan ketepatan yang cukup baik.

\subsection{Implementasi Hybrid DSS}

Setelah mengolah data secara manual dengan menggunakan metode hybrid SPK, maka perlu dilakukan pengujian data dengan membangun aplikasi hybrid DSS menggunakan bahasa pemrograman Java dan database MySQL. Dengan adanya aplikasi hybrid DSS ini dapat memudahkan dosen penguji untuk mengambil keputusan dengan cepat dan akurat.

\section{Halaman Menu Proses Metode AHP}

Pada halaman ini merupakan halaman proses data penilaian ujian komprehensif menggunakan metode AHP untuk menentukan nilai bobot dan menentukan konsistensi dari data perbandingan berpasangan. Adapun hasil tampilan proses perhitungan AHP dapat dilihat pada Gambar 3.

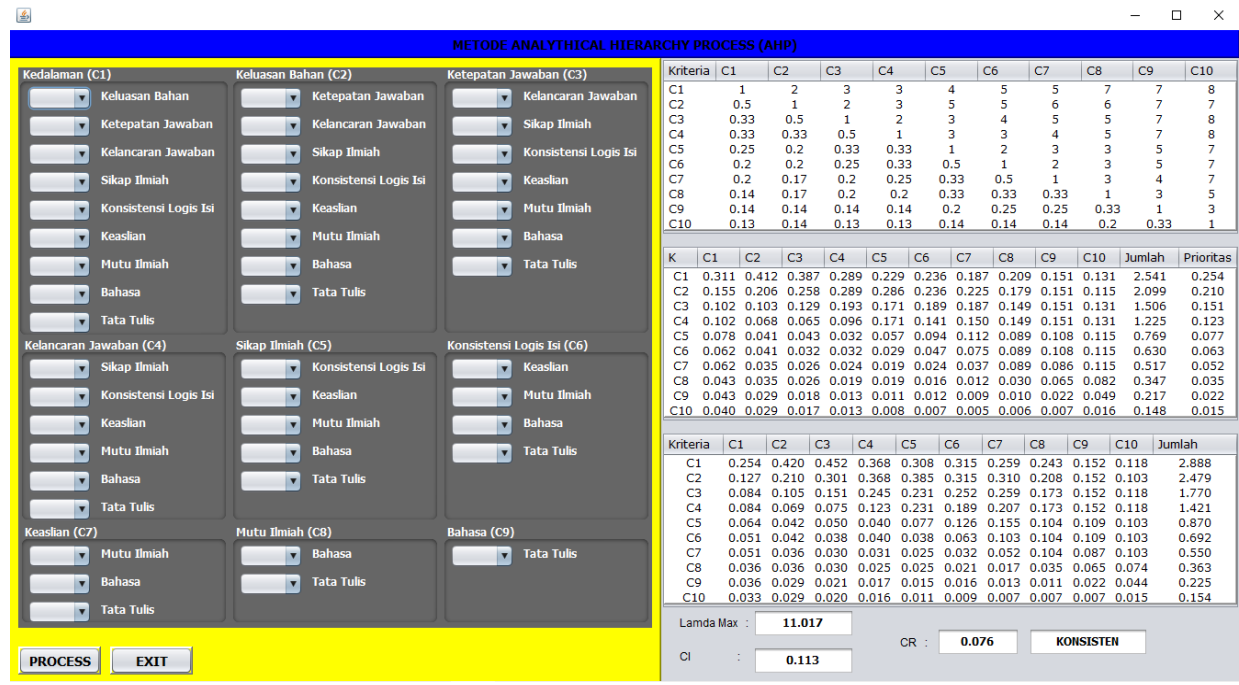

Gambar 3. Halaman Proses Perhitungan Metode AHP

\section{Halaman Menu Metode TOPSIS}

Setelah membuka halaman menu proses metode AHP, maka akan dilanjutkan kehalaman menu metode
TOPSIS. Pada halaman ini user dapat mengetahui hasil akhir berupa perangkingan. Adapun hasil tampilan proses perhitungan Topis dapat dilihat pada Gambar 4.

DOI: https://doi.org/10.29207/resti.v5i6.3587

Lisensi: Creative Commons Attribution 4.0 International (CC BY 4.0) 


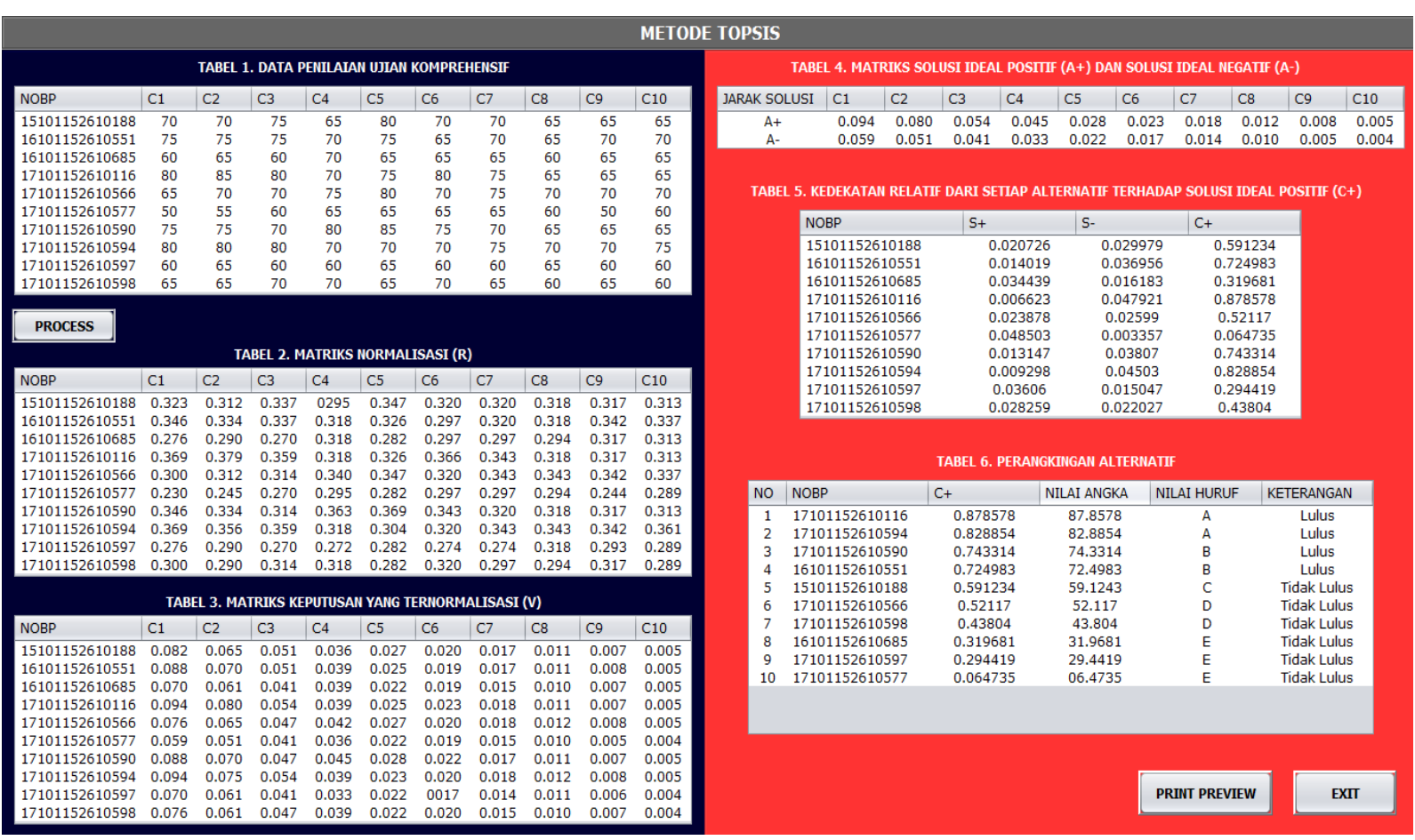

Gambar 4. Halaman Proses Metode TOPSIS

\section{Halaman Laporan Perangkingan}

Laporan yang dihasilkan dari pengolahan data dengan menggunakan metode hybrid DSS ini berupa perangkingan, pada halaman ini user dapat mengetahui mahasiswa yang lulus dan tidak lulus dalam sidang kompre dan mahasiswa yang memperoleh nilai tertinggi dan terendah dalam bentuk perankingan. Adapun hasil laporan perangkingan dapat dilihat pada Gambar 5.

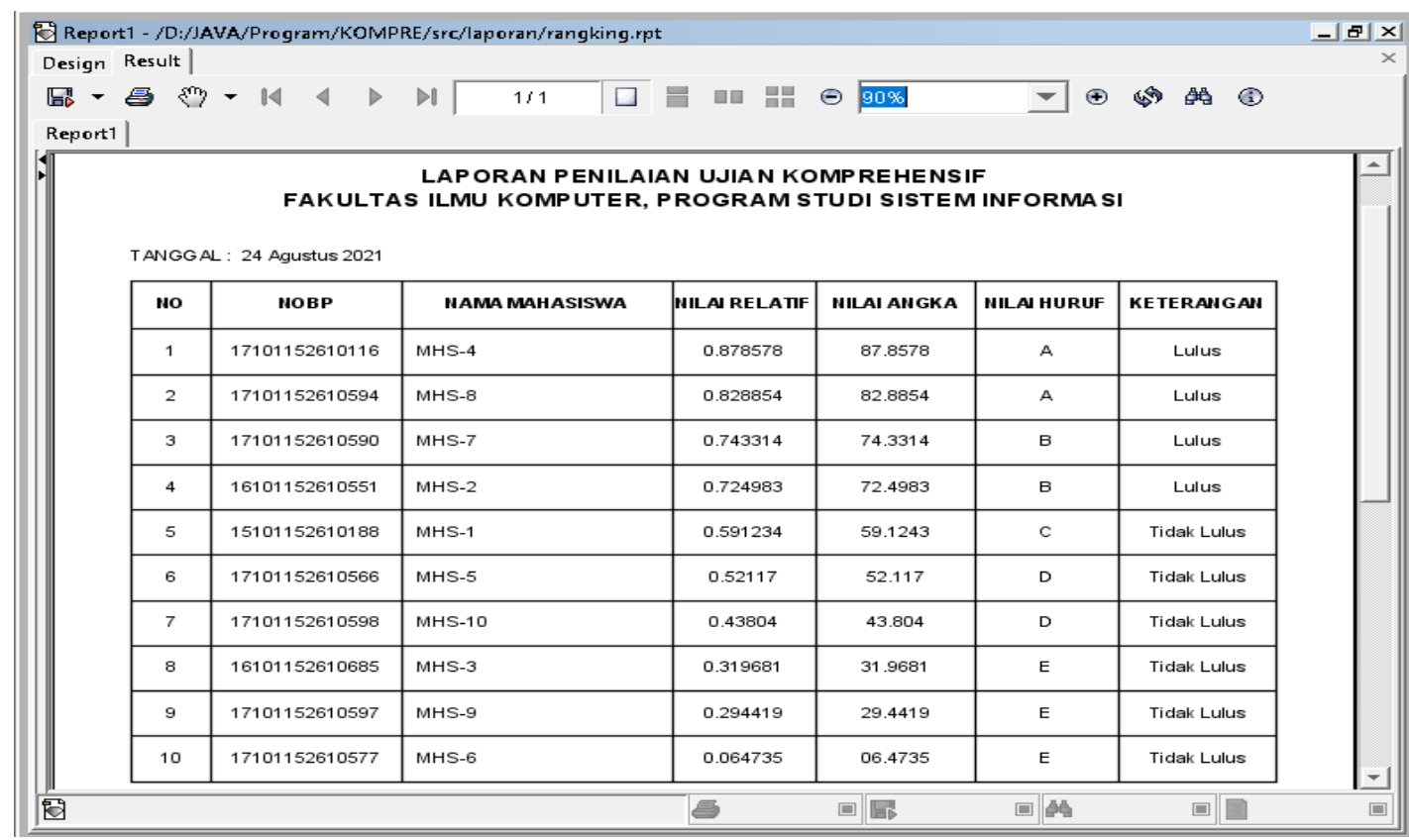

Gambar 5. Laporan Perangkingan

\section{Kesimpulan}

Berdasarkan hasil dan pembahasan yang telah dilakukan penentuan hasil kelulusan dapat ditentukan dengan menggunakan metode HDSS. Metode ini mampu memberikan keterbaharuan konsep dan model dengan menerapkan pengabungan metode AHP dan TOPSIS untuk memberikan keluaran yang dapat dijadikan 
rujukan dalam pengambilan keputusan. Hasil proses analisis AHP memberikan masukan berupa pembobotan terbaik pada indikator yang digunakan. Tidak hanya itu kinerja TOPSIS juga mampu menghasilkan perankingan berdasarkan jarak solusi ideal positif dan jarak solusi ideal negatif. Berdasarkan hasil keluaran secara keseluruhan dapat disimpulkan bahwa kinerja HDSS memberikan tingkat akurasi $85.86 \%$. Dengan hasil tersebut metode HDSS dapat dijadikan rujukan dalam mengatasi permasalahan untuk menentukan hasil kelulusan.

\section{Daftar Rujukan}

[1] A. Budianita and F. I. Pratama, "Penerapan Algoritma Klasifikasi Dengan Fitur Seleksi Weight By Information Gain Pada Pemodelan Prediksi Kelulusan Mahasiswa," Infotekmesin, vol. 11, no. 2. Politeknik Negeri Cilacap, pp. 80-86, 2020, doi: 10.35970/infotekmesin.v11i2.255.

[2] H. Hartatik, "Optimasi Model Prediksi Kelulusan Mahasiswa Menggunakan Algoritma Naive Bayes," Indonesian Journal of Applied Informatics, vol. 5, no. 1. Universitas Sebelas Maret, p. 32, 2021, doi: 10.20961/ijai.v5i1.44379.

[3] M. A. Al-Marom and S. Wibisono, "Sistem Penunjang Keputusan Rekomendasi Kelulusan dan Pemeringkatan Santri Menggunakan Metode AHP-TOPSIS," Jurnal Ilmiah Media Sisfo, vol. 15, no. 1. LPPM STIKOM Dinamika Bangsa Jambi, p. 49, 2021, doi: 10.33998/mediasisfo.2021.15.1.998

[4] N. Heryana, F. Z. Ghassani, M. A. Usrahmawan, D. Juardi, and A. Solehudin, "Kajian Model Prediksi Ketepatan Kelulusan Mahasiswa: Sebuah Literatur Review," Syntax, vol. 9, no. 1, pp. 54-62, 2020.

[5] R. Damis, "Efektivitas Ujian Komprehensif Dalam Meningkatkan Kompotensi Mahasiswa Prodi Ilmu AqidaH," Aqidah-ta J. Ilmu Aqidah, 2018, doi: 10.24252/aqidahta.v4i1.5173.

[6] G. H. Medika and Z. B. Tomi, "Hubungan Lama Studi dengan Nilai Ujian Komprehensif Mahasiswa Program Studi Pendidikan Matematika IAIN Bukittinggi," Sainstek J. Sains dan Teknol., 2020, doi: 10.31958/js.v12i1.2091.

[7] A. Ardi, D. Aldo, and A. Ahmadi, "Sistem Pendukung Keputusan Menentukan Peserta Jamkesmas Dengan Metode Simple Additive Weighting," J. RESTI (Rekayasa Sist. dan Teknol. Informasi), 2019, doi: 10.29207/resti.v3i2.802.

[8] W. Setiawan, N. Pranoto, and K. Huda, "Sistem Pendukung Keputusan Evaluasi Kinerja Karyawan dengan Metode SMART (Simple Multi Attribute Rating Technique)," J. RESTI (Rekayasa Sist. dan Teknol. Informasi), 2020.

[9] Sunardi, A. Fadlil, and R. Fitrian Pahlevi, "Pengambilan Keputusan Sistem Penjaminan Mutu Perguruan Tinggi menggunakan MOORA, SAW, WP, dan WSM," J. RESTI (Rekayasa Sist. dan Teknol. Informasi), 2021, doi: 10.29207/resti.v5i2.2977.

[10] F. Frieyadie and S. M. Ramadhan, "Penerapan Metode AHP Untuk Membantu Siswa Memilih Jurusan Yang Tepat Di SMK," J. RESTI (Rekayasa Sist. dan Teknol. Informasi), 2018, doi: 10.29207/resti.v2i3.396.

[11] Dodi Guswandi, "Sistem Pendukung Keputusan Pemberian Kredit Menggunakan Metode Analytical Hierarchy Process Pada Bank Perkreditan Rakyat (Bpr) Batang TarusaN," Maj. Ilm. UPI YPTK, 2018, doi: 10.35134/jmi.v25i1.10.

[12] Z. Li, Y. Xue, H. Wang, and L. Hao, "Decision support system for adaptive restoration control of transmission system," J. Mod. Power Syst. Clean Energy, vol. 9, no. 4, pp. 870-885, 2021.

[13] A. I. J. Nisa, R. Prawiro, and N. Trisna, "Analisis Hybrid DSS untuk Menentukan Lokasi Wisata Terbaik," J. RESTI (Rekayasa Sist. dan Teknol. Informasi), 2021, doi: [31] 10.29207/resti.v5i2.2915.

[14] D. R. Sari, A. P. Windarto, D. Hartama, and S. Solikhun,
"Sistem Pendukung Keputusan untuk Rekomendasi Kelulusan Sidang Skripsi Menggunakan Metode AHP-TOPSIS," $J$. Teknol. dan Sist. Komput., 2018.

[15] T. Nurhaeni, I. Handayani, R. A. Nurcahya, and A. Rifaldi, "Sistem Penilaian Sidang Komprehensif Tugas Akhir Skripsi dan Tesis Berbasis Yii Framework Menggunakan Business Intelligence Methodology," Technomedia J., 2020, doi: 10.33050/tmj.v5i1.1330.

[16] M. Yanto, "Penerapan Jaringan Syaraf Tiruan Dengan Algoritma Perceptron Pada Pola Penentuan Nilai Status Kelulusan Sidang SkripSI," J. TEKNOIF, 2017, doi: 10.21063/jtif.2017.v5.2.79-87.

[17] R. Kumar, "A combined AHP and TOPSIS approach for prioritizing the attributes for successful implementation of agile manufacturing," Int. J. Product. Perform. Manag., vol. 69, no. 7, pp. 1395-1417, 2020, doi: 10.1108/IJPPM-05-2019-0221.

[18] S. Pishyar, "A Combined AHP- and TOPSIS-Based Approach in the Assessment of Desertification Disaster Risk," Environ. Model. Assess., vol. 25, no. 2, pp. 219-229, 2020, doi: 10.1007/s10666-019-09676-8.

[19] I. Konstantinos, “A Decision Support System methodology for selecting wind farm installation locations using AHP and TOPSIS: Case study in Eastern Macedonia and Thrace region, Greece," Energy Policy, vol. 132, pp. 232-246, 2019, doi: 10.1016/j.enpol.2019.05.020.

[20] E. Mastrocinque, "An AHP-based multi-criteria model for sustainable supply chain development in the renewable energy sector," Expert Syst. Appl., vol. 150, 2020, doi: 10.1016/j.eswa.2020.113321.

[21] M. Yazdi, "Application of fuzzy fault tree analysis based on modified fuzzy AHP and fuzzy TOPSIS for fire and explosion in the process industry," Int. J. Occup. Saf. Ergon., vol. 26, no. 2, pp. 319-335, 2020, doi: 10.1080/10803548.2018.1454636.

[22] A. K. Singh, "A fuzzy-AHP and M - TOPSIS based approach for selection of composite materials used in structural applications," Materials Today: Proceedings, vol. 26. pp. 3119-3123, 2019, doi: 10.1016/j.matpr.2020.02.644.

[23] M. Abdel-Basset, "A Group Decision Making Framework Based on Neutrosophic TOPSIS Approach for Smart Medical Device Selection," J. Med. Syst., vol. 43, no. 2, 2019, doi: 10.1007/s10916-019-1156-1.

[24] G. Di Bona, "AHP-TOPSIS model to evaluate maintenance strategy using RAMS and production parameters," Int. J. Oper. Quant. Manag., vol. 25, no. 3, pp. 175-201, 2019.

[25] M. B. Anand and S. Vinodh, "Application of fuzzy AHP TOPSIS for ranking additive manufacturing processes for microfabrication," Rapid Prototyp. J., 2018, doi: 10.1108/RPJ10-2016-0160.

[26] I. Herman Firdaus, G. Abdillah, F. Renaldi, and U. Jenderal Achmad Yani J1, "Sistem Pendukung Keputusan Penentuan Karyawan Terbaik Menggunakan Metode Ahp Dan TopsIS," 2016.

[27] L. Lukmandono, M. Basuki, M. J. Hidayat, and V. Setyawan, "Pemilihan Supplier Industri Manufaktur Dengan Pendekatan AHP dan TOPSIS," OPSI, 2019, doi: 10.31315/opsi.v12i2.3146.

[28] I. Petrovic, "A hybridized it2fs-dematel-ahp-topsis multicriteria decision making approach: Case study of selection and evaluation of criteria for determination of air traffic control radar position," Decis. Mak. Appl. Manag. Eng., vol. 3, no. 1, pp. 146-164, 2020, doi: 10.31181/dmame2003134p.

[29] A. K. M. Masum, "A new hybrid AHP-topsis method for ranking human capital indicators by normalized decision matrix," J. Comput. Sci., vol. 15, no. 12, pp. 1746-1751, 2019, doi: 10.3844/JCSSP.2019.1746.1751.

[30] B. Febrilia, "Exploring student mathematical engagement using adapted watson' analytical tool: A qualitative approach," Cakrawala Pendidik., vol. 38, no. 1, pp. 188-202, 2019, doi: 10.21831/cp.v38i1.21478.

31] M. Ahsan, "What do they like and dislike from game-based entrepreneurship learning? A qualitative study," Cakrawala Pendidik., vol. 40, no. 2, pp. 495-507, 2021, doi: 
$10.21831 / \mathrm{cp} . \mathrm{v} 40 \mathrm{i} 2.38858$.

[32] Z. Ayăg and F. Samanlioglu, "Fuzzy AHP-GRA approach to [37] evaluating energy sources: a case of Turkey," Int. J. Energy Sect. Manag., 2020, doi: 10.1108/IJESM-09-2018-0012.

[33] E. Rosiska, "Penerapan Metode Analitycal Hierarchy Process (AHP) dalam Menentukan Mitra Usaha Berprestasi," J. RESTI (Rekayasa Sist. dan Teknol. Informasi), 2018, doi: 10.29207/resti.v2i2.419.

[34] Z. Ayağ and F. Samanlioglu, "A hesitant fuzzy linguistic terms set-based AHP-TOPSIS approach to evaluate ERP software packages," Int. J. Intell. Comput. Cybern., 2021, doi: 10.1108/IJICC-07-2020-0079.

[35] E. R. Arumi and U. Yudatama, "Pemanfaatan Curiculum Vitae dan Sasaran Kinerja Pegawai untuk Penilaian Kinerja Dosen Menggunakan AHP," J. RESTI (Rekayasa Sist. dan Teknol. Informasi), 2017, doi: 10.29207/resti.vli3.57.

[36] M. Sequeira, P. Hilletofth, and A. Adlemo, "AHP-based support tools for initial screening of manufacturing reshoring decisions," J. Glob. Oper. Strateg. Sourc., 2021, doi:
10.1108/JGOSS-07-2020-0037.

C. Surya, "Penilaian Kinerja Dosen Menggunakan Metode TOPSIS (Studi Kasus: Amik Mitra Gama)," J. RESTI (Rekayasa Sist. dan Teknol. Informasi), vol. 2, no. 1, pp. 322 329, 2018, doi: 10.29207/resti.v2i1.119.

[38] B. B. Gardas, R. D. Raut, N. Cheikhrouhou, and B. E. Narkhede, "A hybrid decision support system for analyzing challenges of the agricultural supply chain," Sustain. Prod. Consum., vol. 18, pp. 19-32, 2019.

[39] X. F. Zha, R. D. Sriram, M. G. Fernandez, and F. Mistree, "Knowledge-intensive collaborative decision support for design processes: A hybrid decision support model and agent," Comput. Ind., vol. 59, no. 9, pp. 905-922, 2008.

[40] N. Lestari, I. K. N. Wiyasa, and I. B. S. Manuaba, "Penerapan Model Pembelajaran Somatic, Auditory, Visualization, Intellectualy Berbantuan Multimedia Berpengaruh Terhadap Kompetensi Pengetahuan IPA," J. Media dan Teknol. Pendidik., vol. 1, no. 1, pp. 11-21, 2021. 